\title{
Basel Declaration defends animal research
}

\section{Dialogue with public is key to reducing opposition over the use of lab animals.}

\section{BY ALISON ABBOTT}

A nimal activists last summer set fire to the alpine holiday home of Daniel Vasella, then chief executive of pharmaceutical giant Novartis of Basel, Switzerland, in one of relatively few violent attacks on scientists working with animals in Germanspeaking countries.

But in the past few years these scientists have been feeling the pressure in other ways - from animal activists who have attempted to publicly shame them or have sent threatening e-mails, and from legislation that increasingly restricts the use of animals in basic research.

Now, in a bid to reverse that trend, more than 50 top scientists working in Germany and Switzerland have launched an education offensive. Meeting in Basel on 29 November, they drafted and signed a declaration pledging to be more open about their research, and to engage in more public dialogue.

"The public tends to have false perceptions about animal research, such as thinking they can always be replaced by alternative methods like cell culture," says Stefan Treue, director of the German Primate Center in Göttingen. Treue co-chaired the Basel meeting, called 'Research at a Crossroads', with molecular biologist Michael Hengartner, dean of science at the University of Zurich, Switzerland. Outreach activities, such as inviting the public into universities to talk to scientists about animal research, "will be helpful to both sides".

The Basel Declaration reiterates the legal and ethical requirements of the signatories to reduce the use of animals as far as possible (see 'Lab animals used in Germany'), and to keep their suffering to a minimum. But it also forcefully disputes recent efforts to declare animal use in basic research less acceptable than animal use in experiments that may yield practical benefits. In recent legal cases in the two countries, courts have interpreted national laws as forbidding basic research on primates.

In Bremen, Germany, the local government decided in 2007 not to renew the licence of neuroscientist Andreas Kreiter to work on macaques because the work was "too far from applications"1. This put a stop to his research recording from the animals' brains as they performed simple tasks. The ban still holds.

This echoed a case in Switzerland, where Kevan Martin, a director of the Institute of Neuroinformatics in Zurich, had to halt his research programme to map the functional microcircuitry of the brain of macaques in 2006 after Zurich's authorities declined to renew his licence for primate work ${ }^{2}$. The authorities, which also banned other local projects involving primates, said that Martin's work offended the dignity of the animals - which has been protected in the Swiss constitution since 2004 and would not reap practical benefits for society in the near term.

Martin appealed the decision in Switzerland's supreme court, but in September last year the court upheld the decision.

"That was a shock for the community, and was one of the main motivations for holding

\section{LAB ANIMALS USED IN GERMANY}

The total declined in the 1990s, but has since flattened with growing use of transgenic mice.

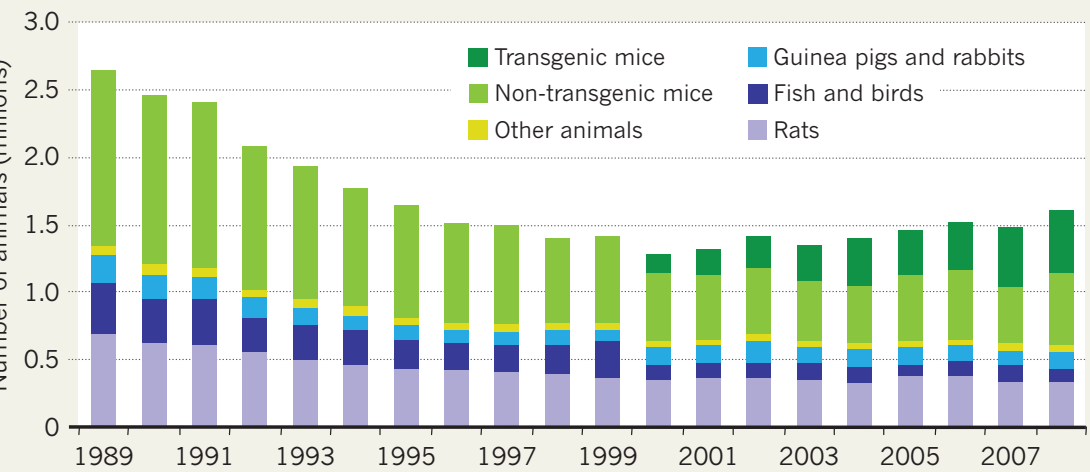

our meeting," says Hengartner. "For the first time in Switzerland, the law was making a distinction between basic and applied research, and arguing that basic research with nonhuman primates is less valuable than applied research," he says. "But in biomedicine they are one and the same; applied research stands on the shoulders of basic research."

Scientists in Germany — which, unlike Switzerland, is a member of the European Union (EU) - had another reason to sign the declaration. In September, the EU approved a directive on animal use in research that must be translated into national law in the $27 \mathrm{EU}$ member states within the next two years. "There are a lot of broad terms in the directive - like

\section{"The severe pain - that could} The animal allow countries like Gerissue is never many to choose wording going to go which makes the legislaaway." tion more restrictive than intended," says Treue. In addition, some of the directive's rules are unscientific, he says. For example, it includes special rules for cats and dogs.

Treue is particularly concerned that the directive bans some experiments outright such as those involving severe pain, or using great apes - rather than allowing ethical committees to regulate them. However, early drafts of the EU directive were much worse, says Treue - one of many scientists who talked to EU parliamentarians to help to ensure that a ban on basic research using primates was removed ${ }^{3}$.

In the United Kingdom, similar initiatives coupled to animal terrorism laws helped to cut extremism, says Mark Matfield, director of the London-based European Biomedical Research Association, which represents animal researchers across Europe. "Being open and discussing with the public why you sometimes need to use animals is a reliable and tested idea which improved the climate for research in Britain."

The declaration will now be sent to deans of medicine and other research leaders in Germany and Switzerland to garner support. The organizers hope to go on to promote it internationally. "The animal issue is never going to go away," says Treue. "We need solidarity among all researchers." — SEE EDITORIAL, P.731

1. Schiermeier, Q. Nature 455, 1159 (2008).

2. Abbott, A. Nature 453, 833 (2008).

3. Abbott, A. Nature 464, 964 (2010) 